9. Pleshakov, N. A. (1987). Vlyianye srokov poseva na prorastanye semian y urozhai podsolnechnyka [Impact of planting dates on seed germination and sunflower harvest]. Biul. nauch.-tekh. ynform. po maslychnym kulturam. Krasnodar, vol. 1, pp. 21-24.

10. Pustovoit, V. S. (1990). Yzbrannye Trudy [Selected Works]. Moscow: Ahropromyzdat, 367 p.

11. Andriienko, A. L. (2013). Yak virno vybraty strok sivby soniashnyku? [How to choose the right time of sunflower sowing?]. Ahronom, vol. 1, pp. 178-184.

12. Trotsenko, V. I., Butenko, A. O. (2002) Osoblyvosti nasinnytstva sortiv soniashnyku v Lisostepovii zoni Ukrainy [Peculiarities of sunflower seed production in the Forest-Steppe zone of Ukraine]. Nauchnye trudy Krymskoho HAU. Symferopol, vol. 72, pp. 163-166.

13. Sydorenko, Yu. Ya., Turchyn, V. V., Vasylenko, Y. A., Kharchenko, N. L. (1990). Po yntensyvnoy tekhnolohy [By intensive technology]. Tekhnycheskye kul'tury, vol. 2, p. 20.

14. Oleksiuk, O. M. (2000). Vplyv sposobiv sivby i hustoty stoiannia roslyn na urozhainist hibrydiv soniashnyka v Pivnichnii chastyni Stepu Ukrainy [Influence of sowing methods and plant density on yield of sunflower hybrids in the Northern part of the Steppe of Ukraine]. Avtoref. dys. na zdobuttya nauk. stupenya kand. s.-h. nauk. Dnipropetrovsk, $16 \mathrm{p}$.

\title{
POSITIVE EFFECT OF DEFERMENT SEEDING CAMPAIGN FOR WINTER WHEAT DUE TO FALL DROUGHT IN EAST OF UKRAINE
}

\section{Tetiana Tretiakova ${ }^{1}$}

DOI: https://doi.org/10.30525/978-9934-26-002-5-49

Introduction. The Steppe of East Ukraine is a specific drought region which has strong wind and high summer temperature. Last ten years rainfall is declining. That is why agricultural companies change management, timing and use moisture saving technology. They are facing new obstacles such as absent rainfall in September (ten years ago normal was 28-35 mm of rainfall during September), 0\% moisture in one-meter soil.

Seeding terms for winter wheat, considering the characteristics of the region:

- Early sowing 25.08-05.09 is used on areas that were cultivated but not sown in a calendar year, there is no predecessor, due to which moisture can be retained on them

\footnotetext{
${ }^{1}$ State Institution «Luhansk Taras Shevchenko National University», Ukraine
} 
- Traditional sowing 05.09-20.09

- Late 20.09-25.09

Sowing times are adjusted depending on weather conditions and weather forecasts (precipitation and average daily temperature), [1, p. 63-74] as well as agronomic and economic conditions [2]. Taking this into account, the sowing dates have traditionally shifted within September. During the study, it was proposed to postpone the sowing date to October [3, p. 10, 26-29]. This was due to the fact that at the site of the experiment there is a moisture deficit in the post during the traditional sowing period and a sufficient period of average daily temperatures for the autumn vegetation of later sowing. Due to this circumstance was accepted a decision to conduct in-field research about deferment seeding nearest to forecast rainfall. Considering that seeding time shifted later than late seeding time in region research was conducted in the first year at an area of one hectare, second year at 300 hectares and third at 450 hectares.

Materials and methods. Four varieties of winter wheat were used, with different growing periods on plots. Plots with different sowing dates were placed on one field, each plot was randomly placed and repeated six times.

The following measurements were made: date of emergence, visual assessment of seedlings, number of emerged plants per $1 \mathrm{~m} 2$ and 10 meters in a row, height of wheat, number of ears, number of grains per ear, total yield per hectare [4, p. 28; 5, p. 194].

All treatments in all areas were identical from soil preparation to pest management and top dressing.

The seeds were treated with a fungicide-insecticidal mixture with the addition of microelements just before sowing (day to day). Sowed with a grain seeder with a row spacing of $15 \mathrm{~cm}$ to a depth of $3-4 \mathrm{~cm}$, with complex mineral fertilizer.

Results. The weather conditions and soil moisture were negative for winter wheat emerging. In the 2017 year, 120 days of drought preceded seeding. In the 2018 year, 97 days of drought (before this time were rainfall approximately 2-3 mm). In the 2019 year, 95 days of drought (before this time there was rainfall approximately 2-3 mm).

First year difference between emergent dates was visually observed. Early emergent plants were lighter color, leaves from $0.75 \mathrm{~mm}$ to1.2 $\mathrm{mm}$ narrower, ends of roots were a slightly dried, up to harvest plants were higher up to $10 \mathrm{~cm}$.

Next to years plants emerge at the same time. That is why any difference in emergent plants were not observed. During fall vegetation plants of winter wheat which were sown early were damaged by insects, temperature was lower than recommended for applying insecticide. Better it was observed in early spring. 
The studies carried out show that the autumn drought and lack of moisture in general negatively affect the development of plants, which negatively affects the overall crop yield. Seedlings received at the same time. According to data from Ukrhydrometcenter the last three years region has had $0-10 \%$ from the norm of rainfall during September, 30-50\% during October and during winter period 2019/2020 were half of rainfall norm. Also, a company, which gives a place for study, has its own instruments and devices to collect and count precipitation, soil moisture, and other necessary data.

The results are shown in the table 1 below:

Table 1

Comparison the results depending of seeding date

\begin{tabular}{|c|c|c|c|}
\hline Year of study & Seeding date & $\begin{array}{c}\text { Date of emergent } \\
\text { plant }\end{array}$ & Yield \\
\hline 2017 & $15.09-20.09$ & $15.10-20.10$ & $3,2-3,4 \mathrm{t} / \mathrm{ha}$ \\
\hline & 26.10 & $30.10-31.10$ & $3,5-3,7 \mathrm{t} / \mathrm{ha}$ \\
\hline 2018 & $10.09-20.09$ & $15.10-22.10$ & $2,2-2,5 \mathrm{t} / \mathrm{ha}$ \\
\hline & $01.10-10.10$ & $20.10-22.10$ & $4,6-4,7 \mathrm{t} / \mathrm{ha}$ \\
\hline 2019 & $07.09-17.09$ & $09.10-11.10$ & $3,5-3,7 \mathrm{t} / \mathrm{ha}$ \\
\hline & $01.10-05.10$ & $09.10-11.10$ & $5,5-5,7 \mathrm{t} / \mathrm{ha}$ \\
\hline
\end{tabular}

Side effects have a positive impact on insecticide treatment. Due to the long period between seed treatment, protection time and plant emergence later sowing has the advantages. The temperature after plant emergence normally is too low for applying insecticides in fall season. That is why high-quality seed treatment is necessary and impacts the total stand of crops.

The plant injury mostly by Chloropidae are higher compared later sowing are:

-2017 year $-10-12 \%$;

-2018 year $-29-30 \%$;

-2019 year $-25-29 \%$.

As shown above fall injury has a straight impact to yield.

Next one advantage in preventing growing in insufficient moisture [6, p. 47]. The study shows that $10 \%$ moisture in soil is enough to start growing but not enough for root development and plant growth, that is all visually observed. In 2018-year damaged areas are placed as uneven spots within fields. The total amount of damaged areas were up to $17 \%$ (first emerged plant).

Discussion and conclusion. The specific field research is impossible to have the same result compared to different years due to a number of obstacles, such as whether, year-round precipitation, temperature, soil conditions and many others. 
To conclude all from above, the shifting seeding time to later has few advantages such as:

- rise yield;

- better insect protection;

- prevent plant losses and damages due to lack of moisture.

Deferment of the seeding campaign for winter wheat up to 10 days compared to traditional seeding time has a positive effect on increased yield in Steppe of East Ukraine. Shifting seeding time to forecast rains in fall drought has a side effect. It is better insecticide control due to shorter time between treating seeds and emergent plants.

\section{References:}

1. Grushka, I. G., \& Dmitrenko, V. P. (1969). O raschote ozhidayemykh srokov poseva ozimoy pshenitsy i otsenka yego effektivnosti [On the calculation of the expected timing of winter wheat sowing and an assessment of its effectiveness]. Kyiv: Trudy UkrNIGMI. (in Russian)

2. URL: https://meteo.gov.ua/ua/33345/forecast/monthly_and_season_forecast/

3. Ulich, L. I. (2007). Stroky sivby ozymoi pshenytsi v umovakh zmin klimatu [Sowing of winter wheat in the conditions of climate change]. Visnyk ahrarnoi nauky. (in Ukrainian)

4. Omeljuta, V. P. (1986). Oblik shkidnykiv i khvorob siljsjkoghospodarsjkykh kuljtur / za red. V. P. Omeljuty [Insects and diseases accounting in agricultural crops]. Kyiv: Urozhaj. (in Ukrainian)

5. Dospekhov, B. A. (1967). Osnovy metodiki polevogo opyta [Basics of the field research methodology]. Moscow: Prosveshchenie. (in Russian)

6. Netis, I. T. (2004). Ozyma pshenytsia v zoni Stepu [Winter wheat in Steppe region]. Kherson: Ailant. (in Ukrainian) 